\title{
SOCIAL TRUST AS AN UNDERLYING SUBSTANCE OF CULTURAL PREFERENCES
}

\author{
Marin Paunov ${ }^{1}$ \\ e-mail:paunovm@abv.bg
}

\begin{abstract}
The role and the importance of social trust have been objects of a comparatively welldefined interest among investigators with sociology and social psychology backgrounds. Unfortunately, this is not so true when it comes to economists. In Economics, even the link between culture and economic development still lacks the necessary attention. On the other hand, in order to explain this link, it will be of help and importance to take social trust into consideration both directly and as an infrastructural element of some important cultural dimensions. This article - being generally with a nature of an overview - attempts to show social trust namely as such an element, offering a framework for its interpretation and showing the correlational link between trust and several cultural constructs. This will hopefully help future modelling when it comes to investigating correlational and causal links between economic parameters and generalized social trust.
\end{abstract}

Key words: social trust, cultures, society, values

JEL: Z10, Z13

\section{Introduction}

One finds a not quite explicit but palpable conviction in the humanities community that trust does matter and it is „one of the most important synthetic forces within society" (Simmel, 1950). Interest in the topic is characterised by strong and increasing fragmentation across scientific areas and research paradigms including sociology, political science, psychology, philosophy, history, management and organisational behaviour, anthropology, etc. Evidence is produced in various fields that trust contributes to economic growth and efficiency in market economies (Bjørnskov, 2013), to social integration, co-operation and harmony in society at large, to life satisfaction, stability and development of democracy, and even to life expectancy and health status. Trust also proves to be at the heart of entire clusters of concepts that are as important in social science theory as in practical daily life: happiness and satisfaction, optimism, health, economic prosperity, educational attainment, welfare, participation and cohesion, civil society,

${ }^{1}$ Prof., D.Sc., Department of Human Resources and Social Security, University of National and World Economy 
among others. Trust is also perceived as a core component of social capital and it is not uncommon to use it as a key indicator of it.

\section{Conceptual frameworks and approaches to trust}

Provided that, overtly or not, trust enjoys recognition for its importance, two significant groups of questions arise: first, what precisely does trust do on the individual and social plane?; and second, where does it come from? Here, at least as regards the second group of questions, Delhey and Newton's conclusions, which set up six basic theoretical frameworks for studying the origin of social trust, deserve attention (Delhey and Newton, 2003).

The six identifiable theoretical constructs about trust fall under two schools of thought or traditions. The first one links trust to individual properties (individual characteristics or parameters such as class, education, income, age and gender). The second one argues that social trust is rather a property of social systems.

The American social-psychological school of thought demonstrated convincingly enough as early as the mid- $20^{\text {th }}$ century through the work of Erikson, Allport, Cattell, Rosenberg, among others, how social trust can be interpreted as a core personality trait of individuals. It is learned in early childhood and tends to persist in later life, changing only slowly thereafter, but modifying itself deeper under the impact of prominent traumatic events. According to social psychologists, social trust is part of a broader set of personality characteristics that include optimism, a belief in co-operation, and confidence that individuals can resolve their differences in the name of living a satisfactory social life together. Trust and optimism are part and parcel of the same general disposition to the world. Conversely, distrust breeds pessimism, misanthropy and cynicism about the possibilities for social and political cooperation.

Some more recent social-psychological concepts have been constructed along these same general lines, the lead contribution among these being that of Eric Uslaner (Uslaner, 1999, 2000). He proves that we learn trust very early in life from our parents. His two studies show that individual levels of trust are among the most stable characteristics over time. He also concludes that social trust is not dependent on the experience of reciprocity. Trustors are not simply paying back trust and good deeds by others. Those who were trusted and supported by others when they were young grow to be more trusting than those who were less trusted and have not been treated as nicely in their early childhood. In addition, Uslaner argues that the sources of social trust lie in optimism and the internal locus of control i.e. the tendency to actively steer the course of one's own life. Optimism leads to higher levels of generalised trust and the latter is more strongly associated with the subjective measure of well-being and individual attitudes to life than with objective, external economic circumstances. 
Besides as within the Erikson-Allport-Cattell-Uslaner social-psychological approach delineated above, trust can be looked upon from an individualistic perspective in another way. Bearing in mind that trusting always involves risks, it is only logical to expect that material well-being should determine the inclination to take risks and that the poor will be less inclined towards it than the rich since the poor cannot afford to lose even a little of what they have if their trust is betrayed (Banfield, 1958). Conversely, the rich stand to lose less in case of betrayed trust, and they may gain much more from a generally trusting behaviour. This general theory is supported by several significant analyses based on the World Values Survey. Social trust tends to be expressed by the 'winners' in society i.e. it is positively correlated with income, status, job and life satisfaction, education and subjective sense of happiness. The strong link between trust, on the one hand, and the subjective experience of happiness and well-being, on the other, has been studied also by Putnam and Inglehart (Putnam, 2000; Inglehart, 1999). Another author - Patterson - concludes that anxiety and insecurity are among the most powerful determinants of distrust (Patterson, 1999).

There are surveys covering the interesting relationships between trust as an individual trait and some personal variables such as gender, age and education. It transpires, for example, that the younger and the oldest cohorts are among the most trusting, trust being lowest with the middle-range age groups. Some studies argue women are less inclined to trust than men but this depends on a host of additional variables and is not a general truth ${ }^{2}$.

Trust studies also manifest different, parallel traditions with respect to trust, regarding it as a property of society rather than of individuals. The core idea here is that individuals participate in, contribute to, or benefit from a trusting culture, or from social and political institutions that encourage the development of trusting attitudes and behaviour.

In line with this approach, respondents and populations are asked a standard question on trust (as in the European Social Surveys (ESS)): "Generally speaking, would you say that most people can be trusted or that you can't be too careful in dealing with people?". It is assumed that this tells us less about individuals' inclinations to trust than about how they estimate the trustworthiness of the society around them (Newton, 2001). Here trust is perceived mainly as the product of experience, and it is assumed that we constantly modify and update our trustful and distrustful feelings in response to changing circumstances. As a result, levels of trust reported in social questionnaires and surveys tell us more about how trustworthy societies and institutions are than about the individual traits of those living in them.

${ }^{2}$ For these and some other conclusions, some of which are used here too, see for example Newton (2001). 
If we assume that social trust is determined by the social circumstances which people find themselves in, it should be statistically associated with certain societal variables. However, there is little agreement about which these variables are and how much weight each one has. One of the theoretical traditions in this respect dates back to the works of John Stuart Mill, Tocqueville, among other, and it is traceable also in contemporary conceptions of social capital (Putnam, 2000). Here I refer to the Voluntary Organisations Theory and the importance of these organisations for building social trust. The core belief here is that we learn to participate by participating, and by participating in regular and close contact with others on a voluntary basis we learn the concepts of trust, reciprocity, cooperation, empathy for others, as well as develop an understanding of common interest and common good. The above-mentioned participation has one particular most important form and it is direct, face-to-face, and sustained involvement in voluntary organisations in the local community.

Naturally, the statistical correlation between membership in voluntary organisations, on the one hand, and the level of social trust, on the other, can be tested by using empirical data. There are some surveys confirming the existence of this correlation, to an extent (Brehm, Rahn, 1997; Stolle, Rochon, 1999). Both their empirical, and methodological and theoretical grounds, however, have been criticised copiously and quite extensively (Torcal, Montero, 1999; Uslaner, 2000).

As a whole, the predominant view is that no matter how important membership in voluntary civil associations for joint action may be, what matters from the point of view of social trust is direct participation in the social networks of everyday life (Yamagishi and Yamagishi, 1993). For most people this means the informal interaction at the family and neighbourhood level, and at the place of work. It also means most of all sporadic, ad hoc participation in the loose networks of people who gather in local bars and pubs, at work, in various interest and hobby groups, and other some such groups that tend to cluster around schools, community centres, and residential areas. There is empirical evidence that such forms of civic engagement and social participation are increasing in modern societies (Verba et al., 1995) and it is they that have a stronger correlation with levels of social trust. Some researchers argue that the forms of social participation under consideration are particularly typical of the socialist societies of Central and Eastern Europe, where they are in contrast to the general feeling of distrust and social scepticism at the macro-social level, helping people solve their daily problems by what many of us know too well as 'sting-pulling and favouritism' (Kolankiewicz, 1994).

A different form of micro-societal (communal) conceptions of trust concentrates on the characteristics of local communities, rather than the informal networks of relationships within them. Some research finds what seems quite noticeable empirically: the smaller the community, the higher trust is likely to be. 
Analysing different types of local communities in the USA, Putnam concludes that “... residents of small towns and rural areas are more altruistic, honest, and trusting than other Americans. In fact, even among suburbs, smaller is better from the social capital point of view" (Putnam, 2000).

The above-mentioned community theory of trust differs from explanations of trust that focus on the characteristics of whole nations or ethno-regional domains. In fact the communal component only goes to complement the other one, which is the leading one. Within it, it is found, for example, that wealthier nations, and those with greater income equality, have higher levels of trust than poorer ones with lower income equality (Inglehart, 1999). Other surveys find a link between trust and social polarization (not only based on income but also on ethnicity and class) (Knack, Keefer, 1997), the scope of the social protection networks and the independence of the court, etc. (Rothstein, Stolle, 2001).

All these different theoretical paradigms about trust are not mutually exclusive. Some of them have certain overlaps. Some explain variations between individuals, others - variations between nations or ethnic groups; some may be better suited to analysing variation at a given point in time, some to explaining changes over time. All of them, however, as mentioned above, have contributed to an enhanced understanding about the origins and role of social trust.

Table 1. Theories of trust and related indicators

\begin{tabular}{|l|l|}
\hline \multicolumn{1}{|c|}{ Theories } & \multicolumn{1}{c|}{ Indicators } \\
\hline $\begin{array}{l}\text { Individual } \\
\text { Personality theory } \\
\text { Success and well-being theory }\end{array}$ & $\begin{array}{l}\text { Income, social status } \\
\text { Life satisfaction, job satisfaction, happiness, anxiety }\end{array}$ \\
$\begin{array}{l}\text { Social } \\
\text { Voluntary organisation theory } \\
\text { Social network theory } \\
\text { Community theory }\end{array}$ & $\begin{array}{l}\text { Membership of voluntary associations } \\
\text { Network of relationships (networking) } \\
\text { City size, satisfaction with the community, community } \\
\text { Societal theory }\end{array}$ \\
& $\begin{array}{l}\text { Safety } \\
\text { Social conflicts, satisfaction with democratic } \\
\text { institutions, political freedom, public safety }\end{array}$ \\
\hline
\end{tabular}

Source: Delhey and Newton (2003).

In the social context, trust, which is an emotion and as such is "felt", is most often associated (Mayer et al., 1995; Bamberger, 2010) with situations where a party in a given social transaction is ready to relay on the other party's actions in a future moment of time or over a future period. The trustor voluntarily relinquishes their control over the other party's actions and, as a consequence, they 
are uncertain about the outcome of these actions, which entails risk of failure or some harm to the trustee if the other party fails to act as desired. To trust means no less than taking such risk or making a judgment that the probability of a negative outcome is sufficiently small i.e. a kind of voluntary vulnerability is in place, relying on positive expectations about the other party's behaviour.

Trust is a key element in human (and not only) relationships. Cognitive neuroscience is providing increasingly distinct indications that the disposition or propensity to trust and the judgment on the trustworthiness of the other party can be traced to the neurobiological structure and activity of a human brain. There are studies that demonstrate that trust can be hormonally altered (by applying oxytocin) (Kosfeld et al., 2005). Trust can be studied also at the supra-personal level in relations among social groups (nations, family, friends, communities, organisations, etc.) and it is not uncommon to bring trust into the picture to describe and explain intra- and inter-group dynamics. In social science trust and its derivatives are a subject of on-going research. In sociology and psychology the level of trust one party has for another is a measure of the latter's faith in the former's honesty, integrity, fairness and benevolence. A related term is 'confidence' but with confidence we rather mean believing in the competence or capabilities and capacity of the other person, i.e. it is not so much about emotion but about rational judgment. Some researchers argue that betrayed trust is easier to forgive if the affected person ascribes it to the other party's lack of sufficient competence as opposed to lack of benevolence or honesty. Economics, on the other hand, conceptualises trust as reliability in transactions. By all means, trust is a heuristic decision-making mechanism enabling a person to cope with complex situations where reliance on purely rational justifications is unrealistic.

In the field of sociology trust is seen primarily through the prism of its place and role in social systems (Luhmann, 1979; Barber, 1983; Giddens, 1984), the interest the topic attracts from sociologists growing with the dynamic social changes in recent decades, referred to as post-modernity. Trust is a social construct, an element of social reality and it does not exist outside our notion of the other. The notion in question can be realistic or not i.e. adequate to the objective reality reflected, but it is this notion that is the carrier of the ingredients of trust. It is not uncommon for trust in sociology to be discussed in parallel with other constructs such as confidence, control, risk, meaning and power. And because trust is a social construct, in principle it is valid to discuss whether trust can be trusted i.e. whether social trust operates as expected (Gambetta, 2000).

In psychology trust is the belief that the trustee will behave as we expect them. Philogenetically, trust starts at the immediate family and grows to others. For Erik Erikson, the author of the psychosocial-crisis-stages concept, developing basic trust is the first step in psychosocial development, which could have a positive or negative outcome for personality development during the first two 
years of one's life. The successful completion of this stage results in a sense of security, a propensity to trust and be optimistic, whilst the unsuccessful completion lays the foundations for a deeper and more lasting sense of mistrust and insecurity, the morbid version of the unsuccessful completion of this stage leading to attachment-related mental disorders (Fonagy, 2010).

Trust is integral to the idea of social influence, because, apparently, it is easier to influence or persuade someone who is trusting. The bottom line is that trust is about choosing to be vulnerable in relation to someone who you believe trustworthy (i.e. when their behaviours have the capacity to invite positive expectations). From the point of view of psychology, trust seems dependent on several of its ingredients or determinants: the perceptions about the other's honesty, their competence and the similarity of values between trustor and trustee. What also matters here is the capacity of a person to be able (inclined) to trust others, which is a composite phenomenon. Many times it has been found that once trust is lost, by violation of one of these determinants, it is very hard to regain, i.e. there is a marked asymmetry in building versus losing trust.

It can be summarised that psychology (especially social psychology) is relatively highly interested in trust, especially its social implications. Here one needs to mention Barbara Misztal's book, in which she attempts to capture all existing meaningful aspects of the concept, concluding that trust has three most important roles in human life. It makes social interactions predictable, it creates a sense of community, and it makes it easier for people to work together (Miztal, 1996). In addition to its social roles, trust may have positive effects on the behaviours, perceptions, and performances of a person. For example, it has a reciprocal relationship with organisational justice perceptions and the two reinforce each other (DeConick, 2010). Again from the point of view of organisations, trust proves influenced by the structuring of the work environment and in turn is a factor for increased cooperation and enhanced performance (DeConick, 2010). Conversely, where trust is absent, projects can fail, especially if this lack of trust has not been identified and addressed (Dirks, Ferrin, 2001).

Social-identity theories too manifest a traditional interest in trust, social identity on its own right having significant cultural aspects. The attitudes and behaviours showing the difference in the perception of the other, depending on their belonging or not to some kind of 'own' group, is based primarily on trust. A whole series of experiments arrive at interesting conclusions, showing that the definition of 'same club' membership can be defined by factors such as being a fan of the same football team, the university they went to, a mutual acquaintance and such like stereotypisations; however, once in place this perception of the other as a member of the same group invites higher levels of trust. This holds 
true even when the attitude towards one's own group is not particularly positive (Foddy and Dawes, 2008; Guth et al., 2006; Brewer, 1999).

In this case the way economics treats trust is of particular interest. In this field of science trust is interpreted as an explanation of the difference between actual human behaviour and the one that can be explained by the individual desire to maximize one's utility. In other words, in economics trust is seen as providing an explanation of the difference between Nash equilibrium and the actual, observed equilibria. Bearing in mind the latest research in cognitive neuroscience and behavioural economics, this is an approach ignoring the presence of a host of other irrational factors determining economic behaviour but at least it acknowledges the importance of trust. In economics trust is also seen as a lubricant of a number of social transitions, reducing the cost of these transactions, enabling new forms of theirs and generally furthering business activities (Morgan, Hunt, 1994; Zheng et al., 2018), including employment and prosperity (Fukuyama, 1996). From this point of view trust is also regarded as a form of social capital. Traditionally, it has been claimed that higher levels of social trust are positively correlated with economic development, while lower levels of trust slow down economic growth.

\section{Trust and culture}

In publications dealing with organisational cultures, or rather - to put it more precisely - with those characteristics of the national values orientation which influence most deeply the organisational cultures in the respective ethno-regional domain and the "philosophy" of organisational behaviour, there are concepts which over the years have earned the status of classics. Among them are the models of Hofstede and Trompenaars \& Hampden-Turner. These authors do not deal directly with trust, but in this case we may be able to use their systematisations in order to find the place of trust as a fundamental variable, intertwined with the cultural dimensions in their models.

Based on the large number of survey studies Hofstede has undertaken, he developed five problem areas (dimensions) that are there for society to consider and that each group resolves in a way that seems most appropriate for the community in question for a relatively long period. Knowledge and views on these problem areas are passed down for generations and this is how cultural identity of the respective group is moulded. The five problem areas that Hofstede uses to delineate culture are: identity, hierarchy, (psychological) gender, truth, and virtue. Irrespective of whether we take Hofstede's model or some of the other influential ones on the topic (for example, that of Trompenaars and Charles Hampden-Turner), we could look for the intrinsic link that exists between social trust, on the one hand, and many of the dimensions of the respective cultural 
model, on the other. Here we shall consider some of the actualisations of this link that come to illustrate the fundamental 'infrastructural' role of trust.

The so-called 'identity' (as per Hofstede's model) tells where the respective culture is placed on the individualism-collectivism axis. This problem area looks into the relationship between the individual and the group, and could be seen as a continuum stretching between individual identity and group identity. The various manifestations of the continuum in question are called differently in various publications: individualistic vs. collectivistic, weak context vs. strong context, specific vs. diffuse, internal vs. external control, monochronic vs. polychronic cultures. This diversity has emerged because many culturalists believe that the identity continuum is important. It goes to show how many aspects there are to this basic social problem area. The role of trust as a determinant here is relatively obvious: due to its very nature, collectivism both involves and calls forth higher levels of trust.

As evidence to the above-said, we could use the ESS Round 7 primary data (Dataset: ESS7-2014, ed. 2.1) covering 38,496 respondents from across European countries in order to obtain the correlation coefficients for generalised trust and several of its more specific manifestations, on the one hand, and the individualisticcollectivistic attitudes, on the other. There is a particularly strong association of collectivism vs. individualism as a cultural dimension with generalised social trust.

Table 2: Correlations between general trust and some of its specific forms

\begin{tabular}{|l|l|c|}
\hline \multirow{2}{*}{$\begin{array}{l}\text { Trust in the Parliament } \\
\text { of the respective country }\end{array}$} & \multicolumn{1}{|c|}{$\begin{array}{c}\text { Most people can be trusted or you } \\
\text { can't be too careful in dealing } \\
\text { with people }\end{array}$} \\
\hline \multirow{2}{*}{$\begin{array}{c}\text { Trust in the legal system } \\
\text { of the respective country }\end{array}$} & Correlation & $\mathbf{0 . 3 6 3}$ \\
\cline { 2 - 3 } & Significance & 0.0000 \\
\cline { 2 - 3 } & Count & 38496 \\
\hline \multirow{2}{*}{$\begin{array}{l}\text { Trust in the police } \\
\text { of the respective country }\end{array}$} & Correlation & $\mathbf{0 . 3 6 1}$ \\
\cline { 2 - 3 } & Significance & 0.0000 \\
\cline { 2 - 3 } & Count & 38496 \\
\hline \multirow{2}{*}{$\begin{array}{l}\text { Trust in the politicians } \\
\text { of the respective country }\end{array}$} & Correlation & $\mathbf{0 . 2 8 9}$ \\
\cline { 2 - 3 } & Significance & 0.0000 \\
\cline { 2 - 3 } & Count & $\mathbf{0 . 3 6 4}$ \\
\hline \multirow{2}{*}{$\begin{array}{l}\text { Most of the time people attend } \\
\text { to themselves (as opposed to helping others) }\end{array}$} & Correlation & 0.0000 \\
\cline { 2 - 3 } & Significance & 38496 \\
\cline { 2 - 3 } & Count & $\mathbf{0 . 4 7 8}$ \\
\cline { 2 - 3 } & Correlation & 0.0000 \\
\hline
\end{tabular}

Source: Author's analysis 
The "power distance" dimension (again as per Hofstede's model) also presupposes an inherent link with trust. In high power distance cultures, managers and staff regard each other as existentially unequal - they believe that hierarchy is based on a kind of natural inequality. Organisations and societies tend to centralise power as much as possible in the hands of fewer people. Subordinates are expected to accept orders about what to do. There are many jobs with controlling roles, structured in steep hierarchies of employees who report to each other. Top to bottom of the hierarchy comparison reveals huge differences in pay levels. The superiors enjoy privileges ('private laws'), the ideal boss, as seen by subordinates, being the benevolent autocrat or the "good father". The visible signs of status in high power distance cultures contribute to the authority of the superiors - the subordinate is highly likely to be proud to tell their neighbour that their boss is driving a bigger car than that of the neighbour's boss. Senior managers are respected more than young ones. Being a victim of abuse of power on the part of your boss is more often interpreted as just a piece of bad lack and there is no clear inclination to seek redemption or compensation in such situations.

In low power distance cultures, managers and staff regard each other rather as existentially equal, while the hierarchical system is merely an operational inequality of the roles in a certain context and is there for the sake of more convenience and efficiency. Roles can be changed or swapped so that today's subordinate can be tomorrow's manager. Organisations and many public structures are quite decentralised, with flat organisational structure and a limited number of controlling staff. Differentiation in pay (income inequality) i.e. the difference between the maximum and minimum levels of pay or income is relatively small. Privileges of those at the top are undesirable. As a rule, superiors should be accessible to their subordinates and the ideal manager is seen as the resourceful (and respected for their resourcefulness) democrat. Status symbols in communities of lower power distance are frowned upon. More and better developed appeals procedures for citizens and subordinates to use are expected to be in place as regards complaints about alleged abuse of office (malfeasance in office).

A key issue under this cultural dimension is the form of hierarchical structure and the procedures bringing it to life i.e. the extent of inequality among people. In high distance power societies no one believes that all are (or even that they should be) equal or that they should enjoy the same prerogatives. Parents will not be children, leaders will not be followers, kings will not be subjects.

In Europe several survey studies (including Hofstede's) have revealed that power distance in Northern and Western European cultures is lower than in Eastern and South European countries. The two regions are divided, roughly speaking and not by coincidence, by the former border of the Roman Empire. Such divide exists also between Anglo-Saxon and Latin cultures. 
In the table below, based on Hofstede's model, some of the most important behavioural tendencies are systematised, as deriving from the difference in power distance and illustrating it well enough (Hofstede, 1980; Hofstede, 1985; Hofstede, 2000; Trompenaars and Hampdon-Turner, 2004).

Table 3: Summary of the major differences between high and low power distance cultures

\begin{tabular}{|l|l|}
\hline $\begin{array}{c}\text { Characteristics typically observed in low } \\
\text { power distance cultures }\end{array}$ & \multicolumn{1}{|c|}{$\begin{array}{c}\text { Characteristics typically observed in } \\
\text { high power distance cultures }\end{array}$} \\
\hline $\begin{array}{l}\text { Use of power needs to be constantly } \\
\text { legitimised and is subject to moral criteria }\end{array}$ & $\begin{array}{l}\text { Interpretations of ethics are flexible } \\
\text { depending on who possesses and uses } \\
\text { power }\end{array}$ \\
\hline $\begin{array}{l}\text { Capabilities, wealth, power and status are } \\
\text { not necessarily interrelated }\end{array}$ & $\begin{array}{l}\text { Capabilities, wealth, power and status } \\
\text { usually come together }\end{array}$ \\
\hline A large middle class is in place & $\begin{array}{l}\text { The middles class is not prominent in the } \\
\text { social structure }\end{array}$ \\
\hline $\begin{array}{l}\text { The assumption is that all should have } \\
\text { equal rights irrespective of whether they } \\
\text { have power or not. }\end{array}$ & $\begin{array}{l}\text { People in power enjoy many privileges } \\
\text { and this is generally considered normal }\end{array}$ \\
\hline $\begin{array}{l}\text { The holders of power try to look less } \\
\text { empowered i.e. they try to mitigate the } \\
\text { sense of power distance. }\end{array}$ & $\begin{array}{l}\text { The holders of power try to look as } \\
\text { impressive as possible i.e. they try to give } \\
\text { prominence to power distance }\end{array}$ \\
\hline $\begin{array}{l}\text { Power is based on formal position, } \\
\text { expertise and the right to determine pay } \\
\text { levels. }\end{array}$ & $\begin{array}{l}\text { Power rests on family and friend circles, } \\
\text { charisma and ability to use force }\end{array}$ \\
\hline $\begin{array}{l}\text { Pluralistic governments } \\
\text { Political spectrum with strong centre and } \\
\text { weaker wings }\end{array}$ & $\begin{array}{l}\text { Political spectrum with weak centre and } \\
\text { strong wings }\end{array}$ \\
\hline $\begin{array}{l}\text { Autocratic and or oligarchic governments } \\
\text { byge income disparities often reinforced }\end{array}$ \\
\hline
\end{tabular}

Source: Author's summary

Even though considered at the micro level, surveys show a strong correlation between trust and power distance (Islamoglu and Börü, 2005). In addition, we can go on to illustrate this correlation using the last element in the above table - income inequality. The expectation is for economies and societies with lower levels of so- 
cial trust to have higher values for income inequality, as measured by the classic Gini coefficient. The data analysis indicates the existence of this very correlation.

Gini coefficient data issued by the Organisation for Economic Cooperation and Development (OECD) and data from surveys by the author for 2016 are provided in figure 1 .

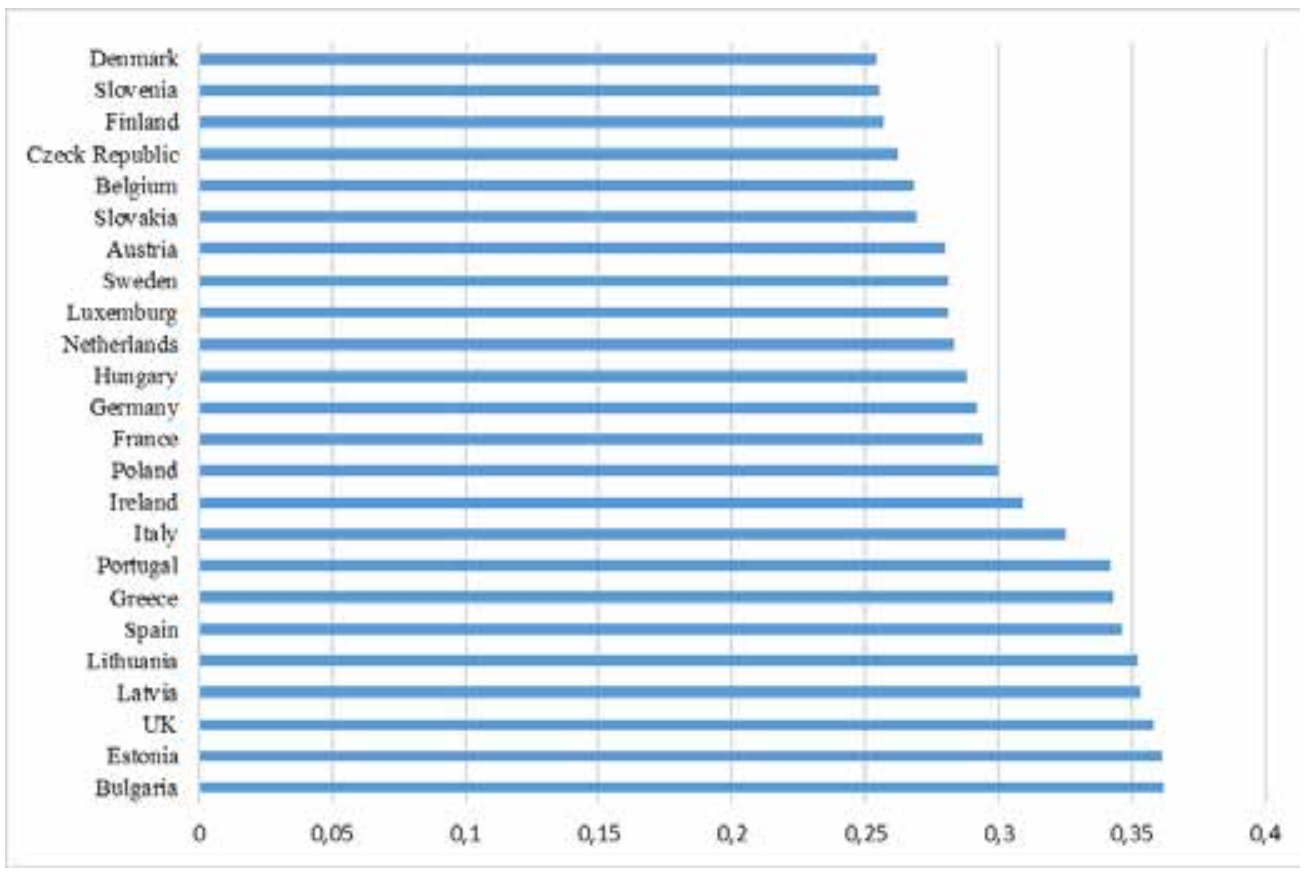

Source: OECD (2021) and author's analysis

Figure 1: Gini coefficient in European countries, 2016

If, in addition, we take into account the Eurostat data for 2015 on the levels of trust in European countries (Eurostat, 2018) we find that the correlation coefficient between the measure for income inequality (disparities) and the levels of social trust is 0,495 .

Truth (ambiguity tolerance) as a cultural dimension is called 'uncertainty avoidance' as opposed to 'uncertainty and ambiguity tolerance'. Striving for certainty is a universal basic human need but the level of its normalcy differs across cultures. The main question with this cultural dimension is how to cope with the unpredictable and the indefinite. It bears a relation to anxiety as a basic human feeling or, in other words, the fear of the unknown. Representatives of low ambiguity-tolerance cultures believe in order and self-discipline where strict rules and one single truth exist. Many people in this type of cultures believe difference 
is dangerous. Representatives of cultures at the other end of the spectrum see the former type of culture as not very foreigner-friendly, since foreigners bring in unclarity, as well as rigid and dogmatic; they are more tolerant of differences.

Hofstede believes that Russia and the Balkan countries have strong uncertainty avoidance cultures, just like Japan, Korea, Mexico, Belgium and France. Germanspeaking countries feel very uncomfortable with uncertainty. English-speaking countries and China tend to be more uncertainty tolerant. Singapore, Jamaica and Denmark are strongly uncertainty tolerant.

Laws and rules are among the basic mechanisms society uses when seeking to avoid uncertainty. In societies avoiding uncertainty there are generally numerous formal laws and informal rules controlling rights and obligations. In organisations there are also many internal rules and regulations to control the process of work, even though in this case power distance plays a role too. Wherever the latter is strong, superiors exercising absolute power can, for some time and to some extent, replace legislation. In essence, the need for laws and rules is not so much based on formal logic; rather, it is based on a psychological one. People in a given community have been programmed since early childhood to feel comfortable in a structured environment where nothing should be left to chance. The emotional need for laws and rules in countries with strong uncertainty avoidance often leads to establishing rules or adopting rule-oriented behaviour, which is pointless, inconsistent or non-functional. In such cultures, not only does the employee like to be told what work needs to be done but they are also happy to get clear, detailed instructions on how to do it. All this does not mean that rules and requirements will not be violated and considered 'formal', though.

In countries with weaker uncertainty avoidance cultures there is an emotional overthrow of a too-many-rules-or-too-formal-norms situation. Rules are coined as a last resort. People in such societies take pride in the fact that many problems can be solved through common sense and cooperation. The Germans with their strong uncertainty avoidance culture are impressed by the social discipline of the British, who queue at bus stops and in shops. There is no law providing for mandatory queuing; queuing is based on a social habit constantly reinforced by social control. Paradoxically enough, rules in weak uncertainty avoidance countries are not as sacred, but are largely and better respected. British queuing, given as an example, is also facilitated by the unemotional calm nature of their culture. As mentioned earlier, weaker uncertainty avoidance also means lower levels of anxiety.

The emotional need for rules in strong uncertainty avoidance societies can turn into a measure of punctuality. This holds most true in relatively low power distance situations so that the behaviour of subordinates does not depend on whether their boss is watching. The Swiss watch industry is a case in point. Today Japanese industries benefit from this aspect of Japanese culture. Punctuality in weak uncertainty avoidance countries is not innate; it is learned, if required. 
Weak uncertainty avoidance countries more often foster innovations since they have higher tolerance for ideas outside the box. On the other hand, they are the losers when it comes to universal roll-out since such a scale of application requires significant sense of detail and punctuality. Details and punctuality are to be found in strong uncertainty avoidance countries.

As a whole, the aspiration for more and detailed norms in the form of laws, procedures, regulations, rules, etc., which are an expression of low ambiguity tolerance, is an obvious indication of an urge for security (intolerance for the lack of it) and of lower levels of public trust. With higher levels of the latter, people would tend to rely on the rational reasoning, benevolence and self-discipline of the others and not so much on imposed norms meant to regulate behaviours.

Hofstede's 2017 data for the Uncertainty Avoidance Index (UAI) and the already used data on public trust for the 24 European countries produce a correlation coefficient between the two parameters of 0,657 .

\section{Conclusion}

It seems to me the above-said is sufficient to illustrate and justify analytically what looks quite obvious anyway: social trust is closely associated with a number of key dimensions that determine cultures. Other correlations can be sought and found too; in this case, however, this is hardly necessary. What matters is to recognise that trust can impact a large number of social and economic variables, both directly and indirectly, through cultural dimensions. This is definitely an area that offers promising space for future more specific research and modelling.

\section{References}

Тромпенаарс, Ф. и Хампдън-Търнър, Ч. (2004). Да се носиш по вълните на културата, Класика и стил, София. (Trompenaars, F. and Hampdon-Turner, Ch., 2004, Da se nosish po vulnite na kulturata, Klasika I stil, Sofia).

Хофстеде, Х. (2000). Култури и организации, Класика и стил, София. (Hofstede, G., 2000, Kulturi I organizacii, Klasika I stil, Sofia).

Bamberger, W. (2010). Interpersonal Trust - Attempt of a Definition, Scientific report, Technische Universität München.

Banfield, E. C. (1958). The Moral Basis of a Backward Society, Glencoe, Ill.: Free Press.

Barber, B. (1983). The Logic and Limits of Trust, Rutgerts University Press.

Bjørnskov, C. (2013). How Does Social Trust Affect Economic Growth?, Working paper 06-2, University of Aarhus, available at: http://pure.au.dk/portal/ files/783/06-2_CB.pdf 
Brehm, J. and Rahn, W. (1997). Individual-Level Evidence for the Causes and Consequences of Social Capital, American Journal of Political Science, 41(3). Brewer, M. B. (1999). The Psychology of Prejudice: Ingroup Love or Outgroup Hate?, Journal of Social Issues, Vol. 55.

DeConick, J. B. (2010). The Effect of Organizational Justice, Perceived Organizational Support, and Perceived Supervisor Support on Marketing Employees' Level of Trust, Journal of Business Research, Vol. 63.

Delhey, J. and Newton, K. (2003). Who Trusts?, European Societies, 5(2), pp. 93-137.

Dirks, K. T., Ferrin, D. L. (2001). The Role of Trust in Organizational Settings, Organization Science, Vol. 12, No. 4, pp. 450-467.

Foddy, M., \& Dawes, R. (2008). Group-Based Trust in Social Dilemmas, in Biel, A., Eek, D., Garling, T. \& Gustafsson, M. (Eds.), New Issues and Paradigms in Research on Social Dilemmas, New York, USA: Springer Science and Business Media.

Fonagy, P. (2010). Attachment Theory and Psychoanalysis, Other Press Professional, Print.

Fukuyama, F. (1996). Trust: The Social Virtues and the Creation of Prosperity, Touchstone Books.

Gambetta, D. (2000). Can We Trust Trust?, in Gambetta, D. (ed.) Trust: Making and Breaking Cooperative Relations, electronic edition, Department of Sociology, University of Oxford, chapter 13.

Giddens, A. (1984). The Constitution of Society: Outline of the Theory of Structuration, Polity Press, Cambridge.

Guth, W., Levati, M. V., Ploner, M. (2006). Social Identity and Trust - An Experimental Investigation, The Journal of Socio-Economics, 37.

Hofstede, G. (1980). Culture's Consequences: International Differences in Work Related Values, Beverly Hills, Sage Publications.

Hofstede, G. (1985). The Interaction Between National and Organisational Value Systems, Journal of Management Studies, No. 22, p. 347-357.

Eurostat. (2018). Data Explorer - Distribution of population by tenure status, type of household and income group - EU-SILC survey.

Inglehart, R. (1999). Trust, Well-Being and Democracy, in Warren, M. E. (ed.), Democracy and Trust, Cambridge: Cambridge University Press, pp. 88-120.

Islamoglu, G. and Börü, D. (2005). Power Distance and Trust, Convivence in Organizations and Society, Avollone, F. and Sinangil H. K. and Caetane, A. (ed.), Quaderni Di Psicologia del Lavoro, Guerini Studio, Milano, Vol. 12, pp.105-112.

Knack, S. and Keefer, P. (1997). Does social capital have an economic payoff? A cross-country investigation', Quarterly Journal of Economics, 112.

Kolankiewicz, G. (1994). Elites in Search of a Political Formula', Daedalus (Summer). 
Kosfeld, M., Heinrichs M., Zak, P. J., Fischbacher, U., and Fehr, E. (2005). Oxytocin Increases Trust in Humans, Nature, 435.

Luhmann, N. (1979). Trust and Power, John Wiley \& Sons.

Mayer, R. C., Davis J. H., Schoorman, F. D. (1995). An integrative model of organizational trust, Academy of Management Review, 20 (3).

Misztal, B. (1996). Trust in Modern Societies: The Search for the Bases of Social Order, Polity Press.

Morgan, R., Hunt, S. (1994). The Commitment-Trust Theory of Relationship Marketing, The Journal of Marketing, 58 (3).

Newton, K. (2001). Trust, Social Capital, Civil Society, and Democracy, International Political Science Review, 22(2).

OECD (2021). Income inequality (indicator), doi: 10.1787/459aa7f1-en

Patterson, O. (1999). Liberty against the Democratic State: on the Historical and Contemporary Sources of American Distrust, in Warren, M. E. (ed.), Democracy and Trust, Cambridge: Cambridge University Press.

Putnam, R. (2000). Bowling Alone: The Collapse and Revival of American Community, New York: Simon and Schuster.

Rothstein, B. and Stolle, D. (2001). Social Capital and Street Level Bureaucracy: an Institutional Theory of Generalized Trust, paper prepared for the ESF Conference on Social Capital: Interdisciplinary Perspectives, 15-20 Sept., Exeter.

Simmel, G. (1950). The Sociology of Georg Simmel, translated and edited by Wolff, K., Glencoe, Ill.: Free Press.

Stolle, D. and Rochon, T. R. (1999). The Myth of American Exceptionalism, in van Deth, J., Maraffi, M., Newton, K. and Whiteley, P. (eds.), Social Capital and European Democracy, London: Routledge.

Torcal, M. and Montero, J. R. (1999). Facets of Social Capital in New Democracies, in van Deth, J., Maraffi, M., Newton, K. and Whiteley, P. (eds), Social Capital and European Democracy, London: Routledge.

Uslaner, E. M. (1999). Democracy and Social Capital, in Warren, M. (ed.), Democracy and Trust, Cambridge: Cambridge University Press.

Uslaner, E. M. (2000). Producing and Consuming Trust, Political Science Quarterly, 115(4).

Verba, S., Schlozman, K. L. and Brady, H. E. (1995). Voice and Equality: Civic Volunteerism in American Politics, Cambridge, Mass.: Harvard University Press. Yamagishi, T. and Yamagishi, M. (1993). Trust and Commitment in the United States and Japan, Motivation and Emotion, 18(2).

Zheng, J., Roehrich, J.K. and Lewis, M.A. (2018). The Dynamics of Contractual and Relational Governance: Evidence from Long-Term Public-Private Procurement Arrangements, Journal of Purchasing and Supply Management, 14(1). 